\title{
Focused direct corrective feedback: Effects on the elementary English learners' written syntactic complexity
}

\author{
Mohammadreza Valizadeh a *(i), Fatemeh Soltanpour b (D) \\ a Cappadocia University, Ürgüp, Nevşehir, 50420, Turkey \\ ${ }^{b}$ Kar Higher Education Institute, Qazvin, 1571, Iran
}

\begin{tabular}{l|l|l} 
Received 23 April 2020 & Received in revised form 8 October 2020 & Accepted 9 March 2021
\end{tabular}

APA Citation: Valizadeh, M., \& Soltanpour, F. (2021). Focused direct corrective feedback: Effects on the elementary English learners' written syntactic complexity. Eurasian Journal of Applied Linguistics, 7(1), 132-150. Doi: $10.32601 /$ ejal.911207

\begin{abstract}
This experimental study, using a pretest-treatment-posttest design, compared the effects of focused direct written corrective feedback and additional writing practice on L2 learners' written syntactic complexity. The participants were 60 Iranian elementary EFL learners, whose L2 proficiency as well as L2 writing syntactic complexity and accuracy were controlled by administering the Oxford Quick Placement Test and a paragraph writing test. They were assigned to two groups: Focused direct corrective feedback (FDCF) and additional writing practice without feedback (No CF). The investigation included five sessions and lasted for three weeks. Every session, each participant wrote a paragraph of descriptive type in class. The experimental group received FDCF, while the control (i.e. No CF) group was provided only with additional writing practice. Lu's (2010) web-based L2 Syntactic Complexity Analyzer was utilized to calculate the five indices of syntactic complexity measures, including mean length of clause (MLC), mean length of sentence (MLS), mean length of T-unit (MLT), clauses per sentence (C/S), and verb phrases per T-unit (VP/T). The MANOVA test revealed no statistically significant difference between the two groups.
\end{abstract}

(C) 2021 EJAL \& the Authors. Published by Eurasian Journal of Applied Linguistics (EJAL). This is an open-access article distributed under the terms and conditions of the Creative Commons Attribution license (CC BY-NC-ND) (http://creativecommons.org/licenses/by-nc-nd/4.0/).

Keywords: Focused written corrective feedback; direct corrective feedback; syntactic complexity; additional writing practice; EFL elementary learners

\section{Introduction}

Corrective feedback (CF) has been a central part of second language (L2) writing instruction worldwide; however, the effectiveness of $\mathrm{CF}$ has been a controversial issue in the field of second language acquisition (SLA) (Karim \& Nassaji, 2020). The debate over the efficacy of written corrective feedback (WCF) dates back to Truscott's (1996) claim that $\mathrm{CF}$ is not only ineffective but it can even be harmful; thus, providing it

\footnotetext{
* Corresponding author. Tel.: +90-534-656-8587

E-mail address: mrvalizadeh2015@gmail.com

http://dx.doi.org/10.32601/ejal.911207
} 
must be stopped. His argument yielded several counter responses from a number of researchers that CF is effective (Bruton, 2009, 2010; Chandler, 2003; Ferris, 1999, 2004, 2006).

Although some of the early studies, which explored the usefulness of the WCF versus no feedback showed no significant advantage for feedback (see e.g. Kepner, 1991; Polio, Fleck, \& Leder, 1998; Semke, 1984), the positive effect of the focused feedback on L2 learners' written syntactic accuracy has been proved in several studies (Bitchener, 2008; Bitchener, East, \& Cartner, 2010; Bitchener, Young, \& Cameron, 2005; Bitchener \& Knoch, 2008, 2009, 2010a, 2010b; Sheen, 2007, 2010a; Sheen, Wright, \& Moldawa, 2009). As for the unfocused WCF methods, some of the early studies did not reveal positive effects for the unfocused CF (Kepner, 1991; Semke, 1984), whereas some of the others have shown promising results (Bonilla López, Van Steendam, Speelman, \& Buyse 2018; Chandler, 2003; Robb, Ross, \& Shortreed, 1986; Sheppard, 1992; Valizadeh, 2020; Van Beuningen, De Jong, \& Kuiken, 2008, 2012). Among the scholars who investigated the effect of the unfocused feedback, Truscott and Hsu (2008) as well as Karim and Nassaji (2020) found that their explored unfocused CF types contributed to the accuracy improvement of the learners' written texts during revision, but they did not result in accuracy gains when writing a new text. Some researchers also compared the effect of focused with unfocused WCF on accuracy gains. Ellis, Sheen, Murakami, and Takashima (2008), Kassim and Ng (2014) as well as Kristia (2018) found that the CF was equally effective for the focused and unfocused groups. On the other hand, Sheen et al., (2009), Farrokhi and Sattarpour (2012) as well as Rahimi (2019) found that the focused feedback was more beneficial than the unfocused one. Frear (2010) indicated that both the focused and unfocused direct CF significantly improved the accuracy of the second writing task in comparison to the control group.

Despite the mentioned points, a gap exists in our knowledge. One of the points that Truscott $(2004,2007)$ argued was that provision of the WCF can affect the complexity of the written text negatively; in other words, receiving the WCF can cause learners to write simplified texts. Truscott (2007) argued that the aim of the CF is to make learners aware of their errors; however, learners are often confused about the received CF. Even when they understand it, this does not mean they have mastered the corrected form, and especially the application of it in other contexts. As a result, a natural reaction of the learners to the $\mathrm{CF}$ is that they hide their weaknesses by avoiding the use of the structures which have been corrected. Truscott even referred to some signs of avoidance in some previously done studies, such as Sheppard (1992), Frantzen (1995), and Chandler (2003). Nevertheless, Truscott (2007) continued that "Unfortunately, it is difficult to judge the strength of the effect [of the CF] or the specific cases in which it is likely to be a serious problem. This is clearly a worthwhile area for further research." (p. 269)

From a theoretical perspective, Kellogg's (1990) Overload Hypothesis, Kellogg's (1996) model of working memory, and limited capacity models of attention (Skehan, 1998) support what Truscott stated in terms of the probable negative effects of the CF 
on learners' writing. According to these models, when several processes must be managed simultaneously, as in writing a text (Torrance \& Galbraith, 2006), attentional demands are very high, and the learners who are writing can be overloaded and unable to attend adequately (Kellogg, 1988); therefore, learners may concentrate their efforts on gaining greater control over items which had already been internalized and are more stable (interlanguage) and avoid expanding their L2 knowledge system (Skehan \& Foster, 2001).

Syntactic complexity is strongly related to the overall L2 proficiency level (Ortega, 2003). Considering the increase in L2 proficiency, it has been stated that syntactic complexity develops in three stages; during the first stage, sentences are first produced as independent, uncoordinated statements, and then are linked by coordination. On the second stage, these utterances are linked by subordination, and on the final stage, the utterances are linked by complexification of the noun phrase (Bardovi-Harlig, 1992; Norris \& Ortega, 2009). Therefore, at beginner and intermediate low proficiency levels, as is the focus of the present research, learners' utterances may show an increase of coordination as for the syntactic growth (BardoviHarlig, 1992; Vyatkina, 2012). Despite the mentioned points, previous studies have indicated that the mentioned three stages of syntactic complexity development may partially overlap, and it is even possible that syntactic complexity decrease again at higher levels of proficiency due to the task and genre effects (Lu, 2011; Ortega, 2003).

To date, very few studies have explored the effect of the WCF on developing syntactic complexity in L2 writing (Chandler, 2003; Fazilatfar, Fallah, Hamavandi, \& Rostamian, 2014; Robb, et al. 1986; Sheppard, 1992; Van Beuningen, et al. 2012). While Sheppard (1992) found a negative effect, Robb et al. (1986) found a significant positive effect for indirect WCF on syntactic complexity. On the other hand, Chandler (2003) and Van Beuningen, et al. (2012) indicated that the WCF did not affect the complexity of L2 learner writing. More recently, Fazilatfar et al. (2014) found a significant positive effect on syntactic complexity of the texts written by the group that had received the comprehensive WCF. In short, not only did the mentioned studies reveal conflicting results (Bitchener \& Ferris, 2012), but they all investigated the effects of comprehensive/unfocused feedback on L2 writing syntactic complexity. Therefore, the issue of the effect of the focused feedback on L2 written syntactic complexity is under-investigated.

Moreover, the results of the studies on the effect of unfocused WCF on L2 complexity gains are not comparable because of their differences in terms of their treatment period, methodology, measurement instruments, genre of writing task, as well as their participants' conditions (e.g., age, proficiency level, L1 background, L2 learning goals, etc.). For example, as Ortega (2015) stated, L1 is "a moderating variable of L2 syntactic complexity" (p. 84). This was also proved in Lu and Ai's (2015), Jiang, Bi, and Liu's (2019), Kuiken and Vedder's (2019), Khushik and Huhta's (2020) as well as Ströbel, Kerz, and Wiechmann (2020) studies. Further, genre/task/content also play roles in syntactic complexity in writing and L2 proficiency is also "a powerful source of influence that modulates syntactic 
complexity" (Ortega 2015, p. 88). These issues were proved in Yoon's (2017) as well as Mostafa and Crossley's (2020) studies. Therefore, the effect of WCF strategies on L2 syntactic complexity is a matter which continues to be a subject of controversy and requires more meticulous studies.

Given the above-mentioned points, this formal classroom research, which was theoretically motivated, was conducted to test the argument of Truscott (2004, 2007), who stated that provision of the $\mathrm{CF}$ can affect the complexity of the written texts negatively, and as a result, aimed to contribute to research-based language pedagogy. It should be noted that the term "formal classroom research" has been borrowed from Ellis (2012, p. 23). This study is true experimental, but classroom-based, meaning it is not a laboratory study; it was conducted in two classes whose students were randomly assigned. Based on Ellis (2009), one of the common strategies that teachers adopt for correcting linguistic errors in students' written work is direct corrective feedback, as a type of explicit correction, so it is critical to investigate whether or not this commonly utilized type of feedback has any detrimental effects on L2 learners' written syntactic complexity. Moreover, as the participants were elementary EFL learners, the focused feedback was selected to ease processing correction for them; however, the utilized CF was of "less focused" type, which "restricts correction to a limited number of preselected types", as explained by Ellis, et al. (2008, p. 356). The current study restricted correction to subject-verb agreement, verb form, and word order. The rationale for selecting the mentioned three grammatical points was that in order to write the descriptive paragraphs, the mentioned structures were important, essential, and highly probable to be used. In short, this study investigated the effects of less focused direct corrective feedback (FDCF) on L2 learners' written syntactic complexity. Following Ellis (2009), via FDCF, not only the error was underlined but also the corresponding correct L2 form was provided; therefore, learners were explicitly provided with the correct form of their errors.

In brief, the following research question was addressed:

Is there any significant difference between the FDCF and No CF groups in syntactic complexity of their descriptive paragraphs?

\section{Method}

\subsection{Sample / Participants}

The participants were selected out of $73 \mathrm{EFL}$ students whose proficiency level was A2, on the Common European Framework of Reference for languages (CEFR) scale. The participants' English proficiency level was carefully controlled by the administration of the pen-and-paper version of Quick Placement Test (QPT) and based on Geranpayeh's (2003) guideline. A total of 68 students got scores ranging from 16 to 23 out of 40 (i.e., the elementary level), based on Geranpayeh (2003); they were selected for the descriptive writing task, which was used to assess the syntactic complexity and accuracy in the written texts (i.e., to ensure the homogeneity of the 
students and as the pretest). The students who were homogeneous in their writing ability (60 students) were assigned to two groups, namely FDCF ( $\mathrm{n}=30$ ), who received focused direct $\mathrm{CF}$, and No $\mathrm{CF}(\mathrm{n}=30)$, who did not receive feedback on their grammatical errors, but was provided with additional writing practice. More information on the participants is provided in Table 1 below.

Table 1. Participants' information

\begin{tabular}{|c|c|c|c|c|c|c|}
\hline & & & & & & \\
\hline & & FDCF & & & No $\mathrm{CF}$ & \\
\hline & Age & & & Age & & \\
\hline & & Female & Male & & Female & Male \\
\hline Mean & 22.43 & & & 22.50 & & \\
\hline SD & 3.01 & & & 2.99 & & \\
\hline Valid Percentage & & 60 & 40 & & 70 & 30 \\
\hline
\end{tabular}

It should be noted that the students' writing ability was measured by exploring not only the syntactic accuracy but also the syntactic complexity of their written texts. In addition, the decision for using the descriptive writing task was made because the participants had already learned how to write simple descriptive paragraphs, appropriate for their English learning level. Moreover, the decision for 30 participants per group was made based on Hatch and Lazaraton's (1991) recommendation that for quantitative data analyses, a minimum of 30 participants is required as the size can produce a distribution of a range of scores. The 60 participants, aged between 18 and 27, included 39 females and 21 males. All of them had passed the elementary EFL courses; they had already completed studying the $3^{\text {rd }}$ edition of the books Top Notch: Fundamentals (Saslow \& Ascher, 2015b) and Top Notch 1 (Saslow \& Ascher, 2015a). The participants' native language (L1) was Persian. The two groups (FDCF and No CF) were in different classes and thus, not in contact with each other during the study.

\subsection{Setting and design}

The study, using pretest-treatment-posttest design, was a product-oriented, true experimental research. There was no systematic bias in assigning the participants to either treatment or control group. Furthermore, following Guénette's (2007) recommendation, the groups in this study had the same teacher; the writing topics and tests were similar as well. This was done to control the possible effects of every other design parameter, except the treatment.

The dependent variable is the syntactic complexity measured in the participants' production from the pretests to the posttests. Syntactic complexity was assessed with five syntactic complexity measures: MLC, MLS, MLT, C/S and VP/T, which are explained in Table 2 below. The independent variable was the FDCF in comparison to additional writing practice, with no feedback. Additionally, the participants' English 
proficiency level and writing ability (i.e., written syntactic complexity and syntactic accuracy) were the control variables. It goes without saying that writing ability includes not only complexity but also accuracy of the written texts in terms of syntactic, lexical, structural, and orthographic issues; however, to the purpose of the present research, only the syntactic complexity of the written texts was focused.

Table 2. Five syntactic complexity measures

\begin{tabular}{lll}
\hline Measure & Code & Definition \\
\hline 1. mean length of clause & MLC & number of words divided by number of clauses \\
\hline 2. mean length of sentence & MLS & number of words divided by number of sentences \\
\hline 3. mean length of T-unit & MLT & number of words divided by number of T-units \\
& & \\
\hline 4. clauses per sentence & C/S & number of clauses divided by number of sentences \\
\hline 5. verb phrases per T-unit & VP/T & number of verb phrases divided by number of T-units \\
\hline
\end{tabular}

\subsection{Instruments}

The following instruments were utilized: Quick Placement Test (QPT), class writing tasks of descriptive type, pretest and posttest. More information about the writing tasks and tests is provided in the Data Collection Procedure Section. In addition, to calculate the syntactic complexity, Lu's (2010) web-based L2 Syntactic Complexity Analyzer was employed. Further, in order to assess the syntactic accuracy, and to control for the differences in text length written by the participants, the following formula, which had also been used by Chandler (2003), Truscott and Hsu (2008), as well as Soltanpour and Valizadeh (2018), was used: [total number of syntactic errors/total number of words] $\times 100$ to calculate a measure of errors per 100 words.

As Geranpayeh (2003, p. 8) explained, "The Quick Placement Test (QPT) is a flexible test of English language proficiency developed by Oxford University Press and Cambridge ESOL to give teachers a reliable and time-saving method of finding a student's level of English." The validity and reliability of the test have been checked and confirmed through Cambridge ESOL quality control procedures.

To assess the syntactic complexity, the automatic approach was used "because it affords speed, flexibility, and reliability" (Crossley \& McNamara, 2014, p. 69). Moreover, human raters are likely to be subjective. They also need training, time to score, as well as monitoring, all of which utilize resources (Higgins, Xi, Zechner, \& Williamson, 2011). The analyzer was already used by several researchers, such as Lu (2011), Fazilatfar et al. (2014), Lu and Ai (2015), Yang, Lu, and Cushing Weigle, 2015), Yoon (2017) as well as Polio and Yoon (2018). Therefore, we understood that the analyzer is recognized and reliable.

To assess the syntactic complexity, the automatic approach was used "because it affords speed, flexibility, and reliability" (Crossley \& McNamara, 2014, p. 69). Moreover, human raters are likely to be subjective. They also need training, time to score, as well as monitoring, all of which utilize resources (Higgins, Xi, Zechner, \& 
Williamson, 2011). This analyzer "produces frequency counts of nine linguistic units in the text-word, sentence, clause, dependent clause, T-unit, complex T-unit, coordinate phrase, complex nominal, and verb phrase-and generates 14 indices of syntactic complexity for the text" (Yang, et al., 2015, p. 58). In the present study, five out of 14 indices were analyzed, as shown in Table 2 . The rationale behind the selection of only these five specific measures was that syntactic complexity is strongly related to the overall L2 proficiency level (Ortega, 2003). During the first stage of syntactic complexity development, sentences are first produced as independent, uncoordinated statements, and then are linked by coordination. (Bardovi-Harlig, 1992; Norris \& Ortega, 2009). Therefore, at beginner and low-intermediate proficiency levels, as is the focus of the present research, learners' utterances may show an increase of coordination as for the syntactic growth (Bardovi-Harlig, 1992; Vyatkina, 2012). Consequently, the mentioned five specific measures were selected because they could be appropriate for the participants' L2 proficiency level and we expected to see some development in the syntactic complexity of their written texts in terms of the five stated measures.

\subsection{Data collection procedures}

The investigation included five sessions and lasted for three weeks. Every session the participants in each group spent about 30 minutes and wrote a paragraph of descriptive type of minimum 100 words in class and turned it in; the texts which students wrote generally included a range of 97 to 110 words.

In experimental group, after the participants turned their written paragraphs in, the teacher-researcher provided them with the specified feedback (i.e. FDCF). The amount of FDCF did not differ a lot among participants as they were homogeneous. For example, in the pretests of both groups, the participants had about seven or eight errors and thus the teacher-researcher provided feedback on about seven or eight errors to each participant's pretest in the FDCF group. The treatment started with the pretest paragraph. Then the students were required to spend about ten minutes looking, analyzing and also revising their corrected text, as recommended by Guénette (2012), so they would be responsible for their learning. Because the participants were homogeneous, the amount of FDCF did not vary much among them, and it was fair to give the same amount of time for the participants to revise their texts. Table 3 shows the sessions and the topics of descriptive types in the experimental group.

Table 3. Sessions and topics in the experimental group

\begin{tabular}{lll}
\hline Week & Session & Topic \\
\hline 1 & 1 (pretest) & Describe one of your friends. \\
\cline { 2 - 3 } & 2 & Describe your best or your favorite vacation. \\
\hline 2 & 3 & Describe the house in which you grew up. \\
\cline { 2 - 3 } & 4 & Describe one of your childhood memories. \\
\hline 3 & 5 (posttest) & Describe your favorite teacher's classroom. \\
\hline
\end{tabular}


Participants in the control group neither received CF nor were involved in any revision activities. Instead, they did a new writing task, so they had the opportunity to practice their writing skills once more. Moreover, the completion of a completely new task required as much time as revising an already written text, as was required in the experimental group. Table 4 indicates the sessions as well as the topics of descriptive types in the control group.

Table 4. Sessions and topics in the control group

\begin{tabular}{llll}
\hline Week & Session & 1st Topic & Extra Topic for Extra Writing Practice \\
\hline 1 & 1 (pretest) & Describe one of your friends. & Describe your favorite person. \\
\cline { 2 - 4 } & 2 & Describe your best or your favorite vacation. & Describe an interesting place you visited. \\
\hline 2 & 3 & Describe the house in which you grew up. & Describe your dream house. \\
\cline { 2 - 4 } & 4 & Describe one of your childhood memories. & Describe a day at your school or work. \\
\hline 3 & 5 (posttest) & Describe your favorite teacher's classroom. & Describe each of your family members. \\
\hline
\end{tabular}

Finally, on the first session of Week three, the posttest was given. The students could spend maximum 30 minutes writing the test paragraph. It should be noted that no participant took the required test twice; further, although the descriptive topics were different in the tests, they were the same for both groups. Considering the fact that genre/task/content play roles in syntactic complexity in writing (Ortega, 2015), descriptive type was the only genre utilized in writing tasks and tests in this study to ensure that the topics were comparable in terms of syntactic complexity.

\section{Results}

\subsection{The normality tests}

The assumption of normality was tested via both the graphic of histogram, and also some numerical ways as proposed by Larson-Hall (2010). The histograms showed that the data were normally distributed. Regarding the numerical methods of assessing normality, the values of skewness and kurtosis statistics were within $+/-1$, based on Phakiti (2010); further, the outcomes of the ratio of skewedness and kurtosis over their respective standard errors were within the ranges of $+/-1.96$, based on Field (2013); therefore, the numerical tests also revealed that the data were normality distributed.

\subsection{Ensuring the homogeneity of the groups}

An independent t-test was conducted to compare the pretest of grammatical knowledge scores for the FDCF and No CF groups. There was no significant difference in scores for FDCF $(\mathrm{M}=19.50, \mathrm{SD}=1.92)$ and No CF $(\mathrm{M}=19.57, \mathrm{SD}=1.94)$; ( $\mathrm{t}(58)=$ $-.13, \mathrm{p}=.89$ ). The magnitude of the differences in the means (mean differences $=-.06$, $95 \% \mathrm{CI}:-1.06$ to .93$)$ was very small. 
In order to ensure that the two groups were homogeneous in terms of their written syntactic accuracy, an independent-samples t-test was done to compare the mean scores of the pretest of writing for the FDCF and No CF groups. There was no significant difference in scores for the FDCF group $(\mathrm{M}=7.80, \mathrm{SD}=.14)$ and No CF (M $=7.79, \mathrm{SD}=.16) ;(\mathrm{t}(58)=.41, \mathrm{p}=.68)$. The magnitude of the differences in the means (mean differences $=.01,95 \% \mathrm{CI}:-.06$ to .09$)$ was very small.

Then, in order to find out whether the two groups were homogenous in terms of the syntactic complexity of their essays, multivariate analyses of variance (MANOVA) were performed because there were several dependent variables (Larson-Hall, 2010; Pallant, 2013; Tabachnick \& Fidell, 2013). In this research, the researchers were interested in comparing groups on a range of syntactic complexity measures, so there were several dependent variables, which were related. In these research situations, MANOVA is utilized based on Larson-Hall (2010), Pallant (2013), as well as Tabachnick and Fidell (2013). MANOVA has already been used by previous researchers, such as Fazilatfar et al., 2014 as well as Kasiri and Fazilatfar (2016), who investigated written syntactic complexity with two groups.

The assumptions of MANOVA (i.e. equal sample sizes, univariate normality, multivariate normality (outliers), multicollinearity and singularity, linearity, and finally, homogeneity of variance matrices) (Pallant, 2013; Tabachnick \& Fidell, 2013) were first examined to be sure that they were met. Fortunately, there were no problems with equal sample sizes in each group and the assumption of univariate normality.

To test for multivariate normality, Mahalanobis distance was calculated (Pallant, 2013; Tabachnick \& Fidell, 2013). The maximum value for Mahalanobis distance for the FDCF and No CF were 14.39 and 19.94, respectively, which were less than the critical value (i.e. 20.52, based on Pallant, 2013), so it was safely assumed that there were no multivariate outliers.

Next, to check for multicollinearity and check the strength of the correlations among the dependent variables, a correlation test was run (Pallant, 2013; Tabachnick $\&$ Fidell 2013). There were no correlations up around .8 or .9, so there was no reason for concern regarding multicollinearity (Pallant, 2013; Tabachnick \& Fidell, 2013.

Then, to assess the assumption of linearity, a matrix of scatterplots was generated between each pair of variables, separately for each group. The scatterplots were roughly oval-shaped (Tabachnick \& Fidell, 2013) or cigar-shaped (Pallant, 2013), so the assumption of linearity was met.

A one-way between groups multivariate analysis of variance (MANOVA) was performed. Five dependent variables were used: MLS, MLT, MLC, C/S, and VP/T. The independent variable was the type of WCF.

Box's test of equality of covariance matrices for pretest of syntactic complexity showed that the assumption of homogeneity of variance-covariance was met (Sig = $.003>.001)$. Levene's test of equality of error variances for the indices of syntactic 
complexity of the pretest revealed that all the Sig. values were over .05, indicating that the assumption of equality of variance for the variables was met as well.

Multivariate tests for pretest of syntactic complexity indicated that the $p$-value was larger than the stringent alpha level $(.84>.05)$, so there was not a significant difference among the two groups on the combined dependent variables, $\mathrm{F}(5,54)=.40$, $\mathrm{p}=.84$; Wilk's Lambda $=.96$; partial eta squared $=.03$. In conclusion, both groups were homogenous in terms of MLS, MLT, MLC, C/S, and VP/T of the written paragraphs.

\subsection{Finding of the research question}

A one-way between-groups MANOVA was performed to investigate the differences between groups (Larson-Hall, 2010; Pallant, 2013; Tabachnick \& Fidell, 2013). Considering the assumptions of MANOVA, no problems were revealed in terms of univariate normality, multivariate normality (multivariate outliers), multicollinearity, and linearity.

A MANOVA was performed to investigate the differences in syntactic complexity in two groups of FDCF and No CF. Five dependent variables were used: MLS, MLT, $\mathrm{MLC}, \mathrm{C} / \mathrm{S}$, and VP/T. The independent variable was the type of WCF.

Box's test of equality of covariance matrices for posttest of syntactic complexity revealed that the assumption of homogeneity of variance-covariance was met (Sig = $.293>.001)$. Levene's test of equality of error variances for all the indices of syntactic complexity of the posttest revealed that all the Sig. values were greater than .05, indicating that the assumption of equality of variance for the variables was also met.

Multivariate tests for posttest of syntactic complexity indicated that the $p$-value was larger than the stringent alpha level $(.81>.05)$, so there was not a significant difference among the two groups on the combined dependent variables, $\mathrm{F}(5,54)=.44$, $\mathrm{p}=.81 ;$ Wilk's Lambda $=.960 ;$ partial eta squared $=.04$. In conclusion, the FDCF did not cause a significant difference in terms of MLS, MLT, MLC, C/S, and VP/T of the written paragraphs.

\section{Discussion and Conclusion}

In this study, Truscott's $(2004,2007)$ argument that provision of WCF can affect the complexity of the written text negatively was investigated. The results indicate no significant difference between the FDCF group and the control one, which only practiced writing. Similarly, Chandler (2003) showed that WCF did not affect the complexity of L2 learner writing. In contrast, Robb et al. (1986) and Fazilatfar et al. (2014) found significant positive effects for the WCF on their investigated complexity measures. Whereas Sheppard (1992) found a negative effect for the WCF on structural complexity, Van Beuningen, et al. (2012) reported that WCF did not make the learners write simplified texts. Nonetheless, as the previously done studies (Chandler, 2003; Fazilatfar et al., 2014; Robb et al., 1986; Sheppard, 1992; Van 
Beuningen et al., 2012) differed from the present study in terms of their treatment, treatment period, methodology, measurement instruments, genre of writing task, as well as their participants' conditions (e.g., age, proficiency level, L1 background, L2 learning goals, etc.), which could all be moderating variables of L2 syntactic complexity, the results found in present study are not comparable with the ones found in previous research.

In spite of the findings of the current study, a more meticulous comparison of the mean scores of the syntactic complexity measures in pre- and post-tests indicate the existence of some differences. Table 5 shows the information.

Table 5. Comparison of the descriptive statistics of the pretest and posttest

\begin{tabular}{|c|c|c|c|c|c|c|c|}
\hline \multicolumn{4}{|c|}{ Pretest } & \multicolumn{4}{|c|}{ Posttest } \\
\hline Indices & Treatment & Mean & $\mathrm{SD}$ & Indices & Treatment & Mean & SD \\
\hline \multirow[t]{2}{*}{ MLS } & FDCF & 40.76 & 3.39 & \multirow[t]{2}{*}{ MLS } & FDCF & 42.30 & 5.14 \\
\hline & No CF & 40.94 & 3.94 & & No CF & 40.66 & 4.43 \\
\hline \multirow[t]{2}{*}{ MLC } & FDCF & 40.89 & 4.04 & \multirow[t]{2}{*}{ MLC } & FDCF & 41.55 & 3.44 \\
\hline & No CF & 41.52 & 4.84 & & No CF & 40.55 & 3.35 \\
\hline \multirow[t]{2}{*}{ MLT } & FDCF & 49.30 & 4.65 & \multirow[t]{2}{*}{ MLT } & FDCF & 50.24 & 4.23 \\
\hline & No CF & 49.26 & 3.90 & & No CF & 49.19 & 4.21 \\
\hline \multirow[t]{2}{*}{$\mathrm{C} / \mathrm{S}$} & FDCF & 1.00 & .05 & \multirow[t]{2}{*}{$\mathrm{C} / \mathrm{S}$} & FDCF & .98 & .06 \\
\hline & No CF & .99 & .08 & & No CF & 1.00 & .05 \\
\hline \multirow[t]{2}{*}{$\mathrm{VP} / \mathrm{T}$} & FDCF & 1.31 & .07 & \multirow[t]{2}{*}{$\mathrm{VP} / \mathrm{T}$} & FDCF & 1.30 & .06 \\
\hline & No $C F$ & 1.31 & .09 & & No $C F$ & 1.32 & .07 \\
\hline
\end{tabular}

As Table 5 reveals, as for the mean scores of the indices MLS, MLC, and MLT, the FDCF caused small improvements although they were not statistically significant based on the Multivariate tests for posttest of syntactic complexity, as stated in the Result Section. Based on Bardovi-Harlig (1992) and Vyatkina (2012), at beginner and low-intermediate language proficiency levels, syntactic development may indicate an increase of coordination. Following Bardovi-Harlig (1992) and Vyatkina (2012), as the participants were at elementary proficiency level, the FDCF could have been able to produce an increase of coordination. This finding can also be supported by McLaughlin's information processing model (McLaughlin, 1990) and Anderson's ACT (Adaptive Control of Thought) model (Anderson, 1993). As Bitchener and Ferris (2012) stated, the models explain that intentional learning, for example, via corrective feedback, can play an important "role in the controlled phase and through 'practice' or 'repeated activation,' language over time becomes automatized." (Bitchener \& Ferris 2012, p. 13). Additionally, these results are in line with Schmidt's Noticing Hypothesis (Schmidt, 1990, 2001). When learners are provided with written CF, they have enough time - and therefore cognitive resources - to consciously pay attention to linguistic forms and compare their output with the received $\mathrm{CF}$, which increases the likelihood of learners' noticing the gaps in their interlanguage (Hulstijn \& Schmidt, 1994; Polio, et al. 1998; Sheen, 2010b), and consequently, the learners' interlanguage 
grammar can be restructured and developed (Gass, 1997; Long, 1996). More recently, Ögeyik (2018, p. 337) acknowledged that "noticing through output oriented tasks [such as writing and CF] generates higher level of perception of L2 knowledge".

On the other hand, based on Table 5, as for the two indices of C/S and VP/T, the FDCF demonstrates very small decrease in the mean scores while the additional writing practice without feedback displays a slight improvement; in other words, the additional writing practice without feedback were more effective, albeit not sufficiently enough to be statistically significant. This can be corroborated by the output hypothesis (Swain, 1985, 1995). Probably producing output allowed learners to reflect on their metalinguistic knowledge and test hypotheses about the L2 grammar, so the produced output was able to promote noticing, so the learners became aware of the gaps and problems in their interlanguage system (Swain, 1985, 1995). In addition, as Ortega (2003) already stated, syntactic complexity is strongly related to the overall L2 proficiency level. Furthermore, Bardovi-Harlig (1992) as well as Norris and Ortega (2009), argued that the L2 learners' utterances are linked by subordination during the upper-intermediate levels of proficiency. As the participants in this study were at elementary level, probably they were not developmentally ready to gain the beneficial effect of the feedback. Besides, this finding, which is in line with the issue of learners' developmental readiness, can also support Truscott's (2007) argument, indicating that learners may have been confused about the received CF because they had probably not mastered the corrected form, and especially the application of it in various contexts, so they may have hidden their weaknesses by avoiding the use of the corrected structures, which could have affected the complexity of their written texts negatively. This finding can also be supported by the Kellogg's (1990) Overload Hypothesis, Kellogg's (1996) model of working memory and limited capacity models of attention (Skehan, 1998). The mentioned scholars' points support what Truscott stated in terms of the probable negative effects of the $\mathrm{CF}$ on learners' writing. According to them, because several processes had to be managed simultaneously while viewing or rewriting a text, attentional demands could have been very high, and the learners could have been overloaded and unable to attend adequately (Kellogg, 1988). Moreover, as Pienemann (1987, 1989, 1998, as cited in Bitchener \& Ferris 2012) explained in his teachability hypothesis and processability theory (PT), "information processing is unlikely to occur if the targeted linguistic forms and structures lie outside a learner's stage of 'readiness"' (Bitchener \& Ferris 2012, p. 15). As a result, the participants in this study may have concentrated their efforts on gaining greater control over items which had already been internalized and were more stable in their interlanguage; thus, they avoided expanding their L2 knowledge system (Skehan \& Foster, 2001) to produce more complex structures in their writing.

In short, learning processes facilitating the development of a learner's interlanguage is very complex (Truscott, 1996). Considering the above-mentioned points, it can be concluded that even though the study revealed no significant difference between the two groups, the length of the course can be critical in gaining results; further, in this study, it was not possible for the researchers to design a 
delayed-posttest, so critics may truly think it is still less likely to generalize the findings. Therefore, an approximate replication of this study is needed through a longer course of instruction using a longitudinal design as well as inclusion of a delayed-posttest.

\section{Suggestions for Further Research}

As it was already mentioned, part of the findings was in line with Truscott's (2007) argument, which stated that error correction could have negative effects on learners' written syntactic complexity because they may avoid the use of the corrected structures due to the weakness in their competence and thereby performance. Moreover, this study restricted correction to subject-verb agreement, verb form, and word order. In spite of this, the current research did not explore whether or not the participants utilized the mentioned grammatical points in their posttests to find the probable signs of avoidance. Therefore, it is suggested that future research investigates this point.

Furthermore, It has truly been argued that some learners benefit more from the WCF than others because of "a variety of reasons such as motivation, learning style, and metalinguistic background knowledge" (Ferris, 2010, p. 197), so it is suggested that future research which address questions and employ designs similar to the present study, consider the social, contextual and individual differences, which may mediate the effect of the WCF.

Finally, as Bitchener and Knoch's (2015) recommended, think-aloud protocols can be collected from the participants while both revising texts and composing new texts in order to "provide in-depth information of how learners process the WCF, which might give an insight into how learning takes place. Findings of such a study could also have direct implications for theories of L2 acquisition" (Bitchener \& Knoch, 2015, p. 412).

\section{The Research and Publication Ethics Statement}

The Ethics Committee/Board approval for this study was obtained from Mr. Mowla Miri, the manager of Milad Nour Language Institute, Tehran, Iran in September/14/2019. No ethical considerations were violated in this study.

\section{The Conflict of Interest Statement}

In line with the statement of Committee on Publication Ethics (COPE), we hereby declare that we had no conflicting interests regarding any parties of this study. This research study is not funded by any organizations or institutions.

\section{References}

Anderson, J. R. (1993). Rules of the mind. Hillsdale, NJ: Lawrence Erlbaum. 
Bardovi-Harlig, K. (1992). A second look at T-unit analysis: Reconsidering the sentence. TESOL Quarterly, 26, 390-395. https://doi.org/10.2307/3587016

Bitchener, J. (2008). Evidence in support of written corrective feedback. Journal of Second Language Writing, 17(2), 102-118. https://doi.org/10.1016/j.jslw.2007.11.004

Bitchener, J., East, M., \& Cartner, H. (2010). The effectiveness of providing second language (L2) writers with on-line written corrective feedback. Ako Aotearoa. Ako Aotearoa Publication. Retrieved from https://akoaotearoa.ac.nz/download/ng/file/group-5/theeffectiveness-of-providing-second-language-writers-with-on-line-writtencorrective-feedback.pdf

Bitchener, J., \& Ferris, D. R. (2012). Written corrective feedback in second language acquisition and writing. New York, NY: Routledge.

Bitchener, J., \& Knoch, U. (2008). The value of written corrective feedback for migrant and international students. Language Teaching Research, 12(3), 409-431. https://doi.org/10.1177/1362168808089924

Bitchener, J., \& Knoch, U. (2009). The relative effectiveness of different types of direct written corrective feedback. System, 37(2), 322-329. https://doi.org/10.1016/j.system.2008.12.006

Bitchener, J., \& Knoch, U. (2010a). Raising the linguistic accuracy level of advanced L2 writers with written corrective feedback. Journal of Second Language Writing, 19(4), $207-$ 217. https://doi.org/10.1016/j.jslw.2010.10.002

Bitchener, J., \& Knoch, U. (2010b). The contribution of written corrective feedback to language development: A ten month investigation. Applied Linguistics, 31(2), 193-214. https://doi.org/10.1093/applin/amp016

Bitchener, J. \& Knoch, U. (2015). Written corrective feedback studies: Approximate replication of Bitchener \& Knoch (2010a) and Van Beuningen, de Jong \& Kuiken (2012). Language Teaching, 48(3), 405-414. https://doi.org/10.1017/S0261444815000130

Bitchener, J., Young, S., \& Cameron, D. (2005). The effect of different types of corrective feedback on ESL student writing. Journal of Second Language Writing, 14(3), 191-205. https://doi.org/10.1016/j.jslw.2005.08.001

Bonilla López, M., Van Steendam, E., Speelman, D., \& Buyse, K. (2018). The differential effects of comprehensive feedback forms in the second language writing class. Language Learning, 68(3), 813-850. https://doi.org/10.1111/lang.12295

Bruton, A. (2009). Improving accuracy is not the only reason for writing, and even if it were ... System, 37(4), 600-613. https://doi.org/10.1016/j.system.2009.09.005

Bruton, A. (2010). Another reply to Truscott on error correction: Improved situated designs over statistics. System, 38(3), 491-498. https://doi.org/10.1016/j.system.2010.07.001

Chandler, J. (2003). The efficacy of various kinds of error feedback for improvement in the accuracy and fluency of L2 student writing. Journal of Second Language Writing, 12(3), 267-296. https://doi.org/10.1016/S1060-3743(03)00038-9

Crossley, S. A., \& McNamara, D. S. (2014). Does writing development equal writing quality? A computational investigation of syntactic complexity in L2 learners. Journal of Second Language Writing, 26, 66-79. https://doi.org/10.1016/j.jslw.2014.09.006

Ellis, R. (2009). A typology of written corrective feedback types. English Language Teaching, 63(2), 97-107. https://doi.org/10.1093/elt/ccn023

Ellis, R. (2012). Language teaching research and language pedagogy. West Sussex, UK: John Wiley \& Sons, Inc.

Ellis, R., Sheen, Y., Murakami, M., \& Takashima, H. (2008). The effects of focused and unfocused written corrective feedback in an English as a foreign language context. System, 36(3), 353-371. https://doi.org/10.1016/j.system.2008.02.001 
Farrokhi, F., \& Sattarpour, S. (2012). The effects of direct written corrective feedback on improvement of grammatical accuracy of high-proficient L2 learners. World Journal of Education, 2(2), 49-57. https://doi.org/10.5430/wje.v2n2p49

Fazilatfar, A. M., Fallah, N., Hamavandi, M., \& Rostamian, M. (2014). The effect of unfocused written corrective feedback on syntactic and lexical complexity of L2 writing. International Conference on Current Trends in ELT, 98, 482-488. Elsevier B.V. https://doi.org/10.1016/j.sbspro.2014.03.443

Ferris, D. R. (1999). The case for grammar correction in L2 writing classes, a response to Truscott (1996). Journal of Second Language Writing, 8(1), 1-11. https://doi.org/10.1016/S1060-3743(99)80110-6

Ferris, D. R. (2004). The "grammar correction" debate in L2 writing: Where are we, and where do we go from here? (and what do we do in the meantime ...?). Journal of Response to Writing, 13(1), 49-62. https://doi.org/10.1016/j.jslw.2004.04.005

Ferris, D. R. (2006). Does error feedback help student writers? New evidence on the short- and long-term effects of written error correction. In K. Hyland \& F. Hyland (Eds.), Feedback in second language writing: Contexts and issues (pp. 81-104). New York, NY: Cambridge University Press.

Ferris, D. R. (2010). Second language writing research and written corrective feedback in SLA: Intersections and practical applications. Studies in Second Language Acquisition, 32(02), 181-201. https://doi.org/10.1017/S0272263109990490

Field, A. (2013). Discovering statistics using SPSS (4th. ed.). London: Sage.

Frantzen, D. (1995). The effects of grammar supplementation on written accuracy in an intermediate Spanish content course. The Modern Language Journal, 79(3), 329-344. https://doi.org/10.1111/j.1540-4781.1995.tb01108.x

Frear, D. (2010). The effect of focused and unfocused direct written corrective feedback on a new piece of writing. College English: Issues and Trends, 3, 57-71. Retrieved from http://flc.nccu.edu.tw/Conference/3rd/paper.pdf

Gass, S. M. (1997). Input, interaction and the development of second languages. Mahwah, NJ: Lawrence Erlbaum Associates.

Geranpayeh, A. (2003). A quick review of the English quick placement test. Extract from Research Notes, 12, 8-10. $\quad$ Retrieved from http://www.lingue.uniss.it/documenti/lingue/what_is_the_QPT.pdf

Guénette, D. (2007). Is feedback pedagogically correct? Research design issues in studies of feedback on writing. Journal of Second Language Writing, 16(1), 40-53. https://doi.org/10.1016/j.jslw.2007.01.001

Guénette, D. (2012). The pedagogy of error correction: Surviving the written corrective feedback challenge. TESL CANADA JOURNAL/REVUE TESL DU CANADA, 30(1), 117126. https://doi.org/10.18806/tesl.v30i1.1129

Hatch, E., \& Lazaraton, A. (1991). The research manual: Design and statistics for applied linguistics. Boston, US: Heinle \& Heinle.

Higgins, D., Xi, X., Zechner, K., \& Williamson, D. (2011). A three-stage approach to the automated scoring of spontaneous spoken responses. Computer Speech and Language, 25(2), 282-306. https://doi.org/10.1016/j.csl.2010.06.001

Hulstijn, J. H., \& Schmidt, R. (1994). Guest editors' introduction. AILA Review, 11, 5-10. Retrieved from http://www.aila.info/download/publications/review/AILA11.pdf

Jiang, J., Bi, P., \& Liu, H. (2019). Writing syntactic complexity development in the writings of EFL learners: Insights from a dependency syntactically-annotated corpus. Journal of Second Language Writing, 46, 1-13. https://doi.org/10.1016/j.jslw.2019.100666 
Karim, K., \& Nassaji, H. (2020). The revision and transfer effects of direct and indirect comprehensive corrective feedback on ESL students' writing. Language Teaching Research, 24(4), 519-539. http://doi.org/10.1177/1362168818802469

Kasiri, F., \& Fazilatfar, M. A. (2016). The impact of task complexity on cognitive processes of L2 writers and writing quality: The case of writing expertise, L1, and lexical retrieval. Procedia - Social and Behavioral Sciences, 232(April), 561-568. https://doi.org/10.1016/j.sbspro.2016.10.077

Kassim, A., \& Ng, L. L. (2014). Investigating the efficacy of focused and unfocused corrective feedback on the accurate use of prepositions in written work. English Language Teaching, 7(2), 119-130. https://doi.org/10.5539/elt.v7n2p119

Kellogg, R. T. (1988). Attentional overload and writing performance: Effects of rough draft and outline strategies. Journal of Experimental Psychology: Learning, Memory, and Cognition, 14(2), 355-365. https://doi.org/10.1037/0278-7393.14.2.355

Kellogg, R. T. (1990). Effectiveness of prewriting strategies as a function of task demands. American Journal of Psychology, 103(3), 327-339. https://doi.org/10.2307/1423213

Kellogg, R. T. (1996). A model of working memory in writing. In C. M. Levy \& S. Ransdell (Eds.), The science of writing: Theories, methods, individual differences and applications (pp. 57-71). Mahwah, NJ: Lawrence Erlbaum Associates.

Kepner, C. G. (1991). An experiment in the relationships of types of written feedback to the development of second language writing skills. Modern Language Journal, 75(3), 305-313. https://doi.org/10.1111/j.1540-4781.1991.tb05359.x

Khushik, G. A., \& Huhta, A. (2020). Investigating syntactic complexity in EFL learners' writing across Common European Framework of Reference. Applied Linguistics, 41(4), 506532. https://doi.org/10.1093/applin/amy064

Kristia, C. V. (2018). The relative effects of focused and unfocused direct written corrective feedback on the accurate use of English articles in Hong Kong primary ESL context. Retrieved from http://libdr1.ied.edu.hk/pubdata/img00/arch00/link/archive/1/instarh/4718.pdf

Kuiken, F., \& Vedder, I. (2019). Syntactic complexity across proficiency and languages: L2 and L1 writing in Dutch, Italian and Spanish. International Journal of Applied Linguistics, 29(2), 192-210. https://doi.org/10.1111/ijal.12256

Larson-Hall, J. (2010). A guide to doing statistics in second language research using SPSS. New York, NY: Routledge.

Long, M. H. (1996). The role of the linguistic environment in second language acquisition. In W. C. Ritchie \& T. K. Bhatia (Eds.), Handbook of second language acquisition (pp. 438468). San Diego, CA: Academic Press.

$\mathrm{Lu}$, X. (2010). Automatic analysis of syntactic complexity in second language writing. International Journal of Corpus Linguistics, 15(4), 474-496. https://doi.org/10.1075/ijcl.15.4.02lu

$\mathrm{Lu}, \mathrm{X}$. (2011). A corpus-based evaluation of syntactic complexity measures as indices of collegelevel ESL writers' language development. TESOL Quarterly, 45(1), 36-62. https://doi.org/10.5054/tq.2011.240859

Lu, X., \& Ai, H. (2015). Syntactic complexity in college-level English writing: Differences among writers with diverse L1 backgrounds. Journal of Second Language Writing, 29, 1627. https://doi.org/10.1016/j.jslw.2015.06.003

McLaughlin, B. (1990). "Conscious" versus "unconscious" learning. TESOL Quarterly, 24(4), 617-634. https://doi.org/10.2307/3587111 
Mostafa, T. \& Crossley, S. A. (2020). Verb argument construction complexity indices and L2 writing quality: Effects of writing tasks and prompts. Journal of Second Language Writing. 49, 1-13. https://doi.org/10.1016/j.jslw.2020.100730

Norris, J., \& Ortega, L. (2009). Towards an organic approach to investigating CAF in instructed SLA: The case of complexity. Applied Linguistics, 30(4), 555-578. https://doi.org/10.1093/applin/amp044

Ögeyik, M. C. (2018). The comparative effectiveness of noticing in language learning. International Review of Applied Linguistics in Language Teaching, 56(4), 337-400. https://doi.org/10.1515/iral-2016-0049

Ortega, L. (2003). Syntactic complexity measures and their relationship to L2 proficiency: A research synthesis of college-level L2 writing. Applied Linguistics, 24(4), 492-518. https://doi.org/10.1093/applin/24.4.492

Ortega, L. (2015). Syntactic complexity in L2 writing: Progress and expansion. Journal of Second Language Writing, 29, 82-94. https://doi.org/10.1016/j.jslw.2015.06.008

Pallant, J. (2013). SPSS survival manual: A step by step guide to data analysis using IBM SPSS (5th. ed.). Berkshire, England: Open University Press.

Phakiti, A. (2010). Analysing quantitative data. In B. Paltridge \& A. Phakiti (Eds.), Continuum companion to research methods in applied linguistics (pp. 39-49). New York, NY: Continuum Companions.

Polio, C., Fleck, C., \& Leder, N. (1998). "If only I had more time": ESL learners' changes in linguistic accuracy on essay revisions. Journal of Second Language Writing, 7(1), 43-68. https://doi.org/10.1016/S1060-3743(98)90005-4

Polio, C., \& Yoon, H. J. (2018). The reliability and validity of automated tools for examining variation in syntactic complexity across genres. International Journal of Applied Linguistics, 28(1), 165-188. https://doi.org/10.1111/ijal.12200

Rahimi, M. (2019). A comparative study of the impact of focused vs. comprehensive corrective feedback and revision on ESL learners' writing accuracy and quality. Language Teaching Research, 1-24. https://doi.org/10.1177/1362168819879182

Robb, T., Ross, S., \& Shortreed, I. (1986). Salience of feedback on error and its effect on EFL writing quality. TESOL Quarterly, 20(1), 83-93. https://doi.org/10.2307/3586390

Saslow, J., \& Ascher, A. (2015a). Top Notch 1 (3rd. ed.). New York, NY: Pearson Education, Inc.

Saslow, J., \& Ascher, A. (2015b). Top Notch Fundamentals (3rd. ed.). New York, NY: Pearson Education, Inc.

Schmidt, R. W. (1990). The role of consciousness in second language learning. Applied Linguistics, 11(2), 129-158. https://doi.org/10.1093/applin/11.2.129

Schmidt, R. W. (2001). Attention. In P. Robinson (Ed.), Cognition and second language instruction (pp. 3-32). Cambridge, UK: Cambridge University Press.

Semke, H. (1984). The effects of the red pen. Foreign Language Annals, 17(3), 195-202. https://doi.org/10.1111/j.1944-9720.1984.tb01727.x

Sheen, Y. (2007). The effect of focused written corrective feedback and language aptitude on ESL learners' acquisition of articles. TESOL Quarterly, 41(2), 255-283. https://doi.org/10.1002/j.1545-7249.2007.tb00059.x

Sheen, Y. (2010a). Differential effects of oral and written corrective feedback in the ESL classroom. Studies in Second Language Acquisition, 32(02), 203-234. https://doi.org/10.1017/S0272263109990507

Sheen, Y. (2010b). Introduction: The role of oral and written corrective feedback in SLA. Studies in Second Language Acquisition, 32(02), 169-179. https://doi.org/10.1017/S0272263109990489 
Sheen, Y., Wright, D., \& Moldawa, A. (2009). Differential effects of focused and unfocused written correction on the accurate use of grammatical forms by adult ESL learners. System, 37(4), 556-569. https://doi.org/10.1016/j.system.2009.09.002

Sheppard, K. (1992). Two feedback types: Do they make a difference? RELC Journal, 23(1), 285-304. https://doi.org/10.1177/003368829202300107

Skehan, P. (1998). A cognitive approach to language learning. Oxford, UK: Oxford University Press.

Skehan, P., \& Foster, P. (2001). Cognition and tasks. In P. Robinson (Ed.), Cognition and second language instruction (pp. 183-205). Cambridge, UK: Cambridge University Press.

Soltanpour, F., \& Valizadeh, M. (2018). Revision-mediated and attention-mediated feedback: Effects on EFL learners' written syntactic accuracy. Advances in Language and Literary Studies, 9(4), 83-91. https://doi.org/10.7575/aiac.alls.v.9n.4p.83

Ströbel, M., Kerz, E., \& Wiechmann, D. (2020). The relationship between first and second language writing: Investigating the effects of first language complexity on second language complexity in advanced stages of learning. Language Learning, 70(3), 732-767. https://doi.org/10.1111/lang.12394

Swain, M. (1985). Communicative competence: Some roles of comprehensible input and comprehensible output in its development. In S. M. Gass \& C. G. Madden (Eds.), Input in second language acquisition (pp. 64-81). Cambridge, UK: Cambridge University Press.

Swain, M. (1995). Three functions of output in second language learning. In G. Gook \& B. Seidlhofer (Eds.), Principle and practice in applied linguistics (pp. 125-144). Oxford: Oxford University Press.

Tabachnick, B. G., \& Fidell, L. S. (2013). Using multivariate statistics (6th. ed.). New Jersey, US: Pearson Education, Inc.

Torrance, M., \& Galbraith, D. (2006). The processing demands of writing. In C. A. MacArthur, S. Graham, \& J. Fitzgerald (Eds.), Handbook of writing research (pp. 67-80). New York, NY: Guilford Press.

Truscott, J. (1996). The case against grammar correction in L2 writing classes. Language Learning, 46(2), 327-369. https://doi.org/10.1111/j.1467-1770.1996.tb01238.x

Truscott, J. (2004). Evidence and conjecture on the effects of correction: A response to Chandler. Journal of Second Language Writing, 13(4), 337-343. https://doi.org/10.1016/j.jslw.2004.05.002

Truscott, J. (2007). The effect of error correction on learners' ability to write accurately. Journal of Second Language Writing, 16(4), 255-272. https://doi.org/10.1016/j.jslw.2007.06.003

Truscott, J., \& Hsu, A. Y. (2008). Error correction, revision, and learning. Journal of Second Language Writing, 17(4), 292-305. https://doi.org/10.1016/j.jslw.2008.05.003

Valizadeh, M. (2020). The effect of comprehensive written corrective feedback on EFL learners' written syntactic accuracy. Advances in Language and Literary Studies, 11(1), 17-26. http://doi.org/10.7575/aiac.alls.v.11n.1p.17

Van Beuningen, C. G., De Jong, N. H., \& Kuiken, F. (2008). The effect of direct and indirect corrective feedback on L2 learners' written accuracy. ITL - International Journal of Applied Linguistics, 156, 279-296. https://doi.org/10.1075/itl.156.24beu

Van Beuningen, C. G., De Jong, N. H., \& Kuiken, F. (2012). Evidence on the effectiveness of comprehensive error correction in second language writing. Language Learning, 62(1), 141. https://doi.org/10.1111/j.1467-9922.2011.00674.x

Vyatkina, N. (2012). The development of second language writing complexity in groups and individuals: A longitudinal learner corpus study. Modern Language Journal, 96(4), 572594. https://doi.org/10.1111/j.1540-4781.2012.01401.x 
Yang, W., Lu, X., \& Cushing Weigle, S. (2015). Different topics, different discourse: Relationships among writing topic, measures of syntactic complexity, and judgments of writing quality. Journal of Second Language Writing, 28, 53-67. https://doi.org/10.1016/j.jslw.2015.02.002

Yoon, H. J. (2017). Linguistic complexity in L2 writing revisited: Issues of topic, proficiency, and construct multidimensionality. System, 66, 130-141. https://doi.org/10.1016/j.system.2017.03.007

\section{Copyrights}

Copyright for this article is retained by the author(s), with first publication rights granted to the Journal.

This is an open-access article distributed under the terms and conditions of the Creative Commons Attribution license (CC BY-NC-ND) (http://creativecommons.org/licenses/by-nc-nd/4.0/). 